\title{
ЕКОНОМIКО-МАТЕМАТИЧНЕ МОДЕЛЕЛЮВАННЯ БІЗНЕСОВИХ ПРОЦЕСІВ
}

УДК 332.053

JEL classification: C43,R15

Замрій А.М.

ORCID ID: 0000-0001-9480-9713

Капустян B.O.

доктор фріз.-мат. наук, професор

ORCID ID: 0000-0002-5035-809X

Національній технічний університет Украӥні «Київський політехнічний інститут імені Ігоря Сікорського»

\section{АНАЛІЗ ГАЛУЗЕВОЇ СТРУКТУРИ КИЇВСЬКОЇ ОБЛАСТІ ТА ВИЗНАЧЕННЯ ГОЛОВНИХ ФАКТОРІВ ВИРОБНИЦТВА У ГАЛУЗІ ЗА ДОПОМОГОЮ ВИРОБНИЧИХ ФУНКЦЙ}

\section{ANALYSIS OF THE INDUSTRIAL STRUCTURE OF THE KYIV REGION AND DETERMINATION OF THE MAJOR FACTORS OF PRODUCTION IN THE INDUSTRY USING PRODUCTION FUNCTION}

Стаття э продовженням дослідження моделі переозброєння Київського регіону в напрямку пошуку та аналізу факторів виробництва, які мають суттєвий вплив на обсяги виробництва галузі. При побудові моделі переозброєння було виявлено, що застосування статистичних показників пов'язаних з загальним капіталом галузі (інвестиції, актив, пасив) та кількості праџюючих, у виробничій функиії, призводить до неадекватних значень еластичності, які не мають економічного пояснення. Тому фактори виробничих функцій для кожної галузі окремо та для секторів в иілому потребують більи детального аналізу. Специфіка изього аналізу полягає в тому, щзо економіку України та ї̈ регіонів не можна віднести до планової або до ринкової, вона знаходиться на перехідному етапі, який має свої властивості. Від ринкового типу вона відрізняється швидкістю змін, значними структурними зрушеннями, інституційними пастками, відсутністю саморегуляції, ресурсами, які незатребувані ринковим попитом, але потребуючі певні витрати на підтримку. У статті була проаналізована галузева структура Київської області у період з 2010 по 2018 роки. Визначена основна рушійна галузь за обсягами виробнищтва. Зроблений якісний аналіз галузі з використанням найпоширеніших факторів виробництва за допомогою апарату виробничих функцій та методів попереднього аналізу потенційних факторів, 
які можуть впливати на обсяги виробництва у галузі. Виявлено недоліки при застосуванні капітальних інвестицій, витрат на оплату прачі, середньооблікової кількості штатних працівників як факторів виробничої функції. Проведений широкий аналіз моделей з залученням великої кількості статистичних показників (23), які можуть впливати на обсяги виробництва у галузі на базі корелячійно-регресійного аналізу та методів попереднього аналізу факторів виробництва. Відібрано модель $з$ найкрашими очінками. На базі факторів виробництва та параметрів моделі зроблено висновки щуодо важливості врахування людського капіталу як активу підприємств та торгівельної галузі в иүілому. Надані окремі рекомендації щуодо розвитку галузі та регіону в иілому.

Ключові слова: виробнича функція, фактори виробництва, людський капітал.

The article is a continuation of the study of the rearmament model of the Kiev region in the direction of finding and analyzing the factors of production that have an impact on the production of the industry. During the constructing of the rearmament model, it was found that the use of statistics related to the total capital of the industry (investment, assets, liabilities) and the number of employees in the production function, leads to inadequate values of elasticity, which have no economic explanation. Therefore, the factors of production functions for each industry separately and for the sectors as a whole need more detailed analysis. The specificity of this analysis is that the economy of Ukraine and its regions can not be attributed to the planned or market type, it is in transition stage, which has its own properties. It differs from the market type by the speed of changes, significant structural changes, institutional pitfalls, lack of self-regulation, resources that are not in demand by market, but require certain maintenance costs. The article analyzes the sectoral structure of the Kyiv region in the period from 2010 to 2018. The main driving industry in terms of production is identified. A qualitative analysis of the industry was done by using the most common factors of production using the apparatus of production functions and methods of preliminary analysis of potential factors that may affect production in the industry. Found cons in the use of capital investment, labor costs, the average number of full-time employees as factors of production function. A broad analysis of the models with the involvement of a large number of statistical indicators (23) that can affect the volume of production in the industry has been done, based on correlation-regression analysis and methods of preliminary analysis of factors of production. The model with the best marks is selected. Based on the factors of production and parameters of the model, conclusions are made about the importance of taking into account human capital as an asset of enterprises and the trade industry as a whole. Some recommendations are provided for the development of the industry and the region as a whole.

Keywords: internal migration, labor resources, human capital.

Вступ. В сучасних умовах децентралізації влади на Україні керування соціально-економічними процесами на рівні регіону, раціональне використання людських та інвестиційних ресурсів, стале економічне зростання не втрачає своєї актуальності і потребує постійного перегляду в умовах ринкової економіки. Інтенсивно йдуть дослідження інституціонального підходу до вирішення проблем та розвитку регіону [1]. 
Поряд 3 цим важливо також застосовувати економіко-математичні моделі для прогнозування та якісного аналізу факторів, які сприяють розвитку регіону. Найбільш розповсюдженими в цій області $є$ агентний підхід [2], моделі економічного зростання, балансові моделі та виробничі функції. Останні в наш час не втрачають своєї актуальності, але потребують адаптації з урахуванням зовнішніх чинників та конкретних особливостей кожного регіону.

Постановка завдання. Мета статті полягає у дослідженні та адаптації виробничих функцій для окремих галузей Київського регіону, які скорегують загальну модель переозброєння регіону [3]; якісному аналізі знайдених факторів виробництва та формування окремих рекомендацій на основі зробленого аналізу щодо напрямку розвитку регіону.

Методологія. У процесі дослідження використано статистичні та економетричні методи дослідження.

Результати дослідження. Основними рушійними галузями у Київській області у розрізі об'ємів випуску, кількості трудових ресурсів та капіталу $є$ : оптова та роздрібна торгівля, промисловість, сільське господарство та будівництво. Ці галузі займають $85 \%$ та 78\% загальної структури за капітальними інвестиціями та обсягом реалізованої продукції і 49\% по кількості зайнятого населення (див. табл. 1). Обгрунтуємо можливість використання виробничих функції до цих галузей економіки. Для цього скористаймося висновками розгорнутих досліджень застосування виробничих функцій для української [4] та російської [5] економік.

Розглянемо на графіку (рис. 1) варіанти факторів виробництва, які найчастіше використовуються при побудові ВФ, а саме капітальні інвестиції, основні фонди, кількість зайнятого населення, витрати на оплату праці та обсяги виробництва для оптової та роздрібної торгівлі. 
Таблиця 1 - Відсоткове співвідношення зайнятого населення, капітальних інвестицій та обсягів реалізованої продукції по галузях до загальної кількості за 2018 рік

\begin{tabular}{|l|l|l|l|}
\hline \multicolumn{1}{|c|}{ Галузь економіки } & $\mathbf{L}$ & $\mathbf{Y}$ \\
\hline Сільське господарство, лісове та рибне господарство & $6 \%$ & $17 \%$ & $9 \%$ \\
\hline Промисловість & $17 \%$ & $27 \%$ & $27 \%$ \\
\hline Будівництво & $4 \%$ & $23 \%$ & $4 \%$ \\
\hline Оптова та роздрібна торгівля; ремонт авт. і мот. засобів & $22 \%$ & $18 \%$ & $48 \%$ \\
\hline Транспорт, складське господарство & $9 \%$ & $4 \%$ & $5 \%$ \\
\hline Тимчасове розміщування й організація харчування & $2 \%$ & $0 \%$ & $1 \%$ \\
\hline Інформація та телекомунікації & $2 \%$ & $0 \%$ & $1 \%$ \\
\hline Фінансова та страхова діяльність & $2 \%$ & $0 \%$ & $0 \%$ \\
\hline Операції з нерухомим майном & $2 \%$ & $3 \%$ & $1 \%$ \\
\hline Професійна, наукова та технічна діяльність & $4 \%$ & $1 \%$ & $1 \%$ \\
\hline Діяльність у сфері адміністративного та доп. обслуг. & $3 \%$ & $2 \%$ & $1 \%$ \\
\hline Державне управління й оборона & $7 \%$ & $3 \%$ & $0 \%$ \\
\hline Освіта & $8 \%$ & $0 \%$ & $0 \%$ \\
\hline Охорона здоров'я та надання соціальної допомоги & $8 \%$ & $1 \%$ & $0 \%$ \\
\hline Мистецтво, спорт, розваги та відпочинок & $2 \%$ & $0 \%$ & $0 \%$ \\
\hline Інші види економічної діяльності & $1 \%$ & $0 \%$ & $9 \%$ \\
\hline
\end{tabular}

* срормовано на основі даних джерела [6]

В таблииі: $K$ - капітальні інвестиції, $L$ - зайняте населення, $Y$ - обсяг реалізованої продукиії. Як зазначають автори [4] виробнича функиія може бути побудована як середнє індексів капіталу та праиі, які визначають індекс випуску. 


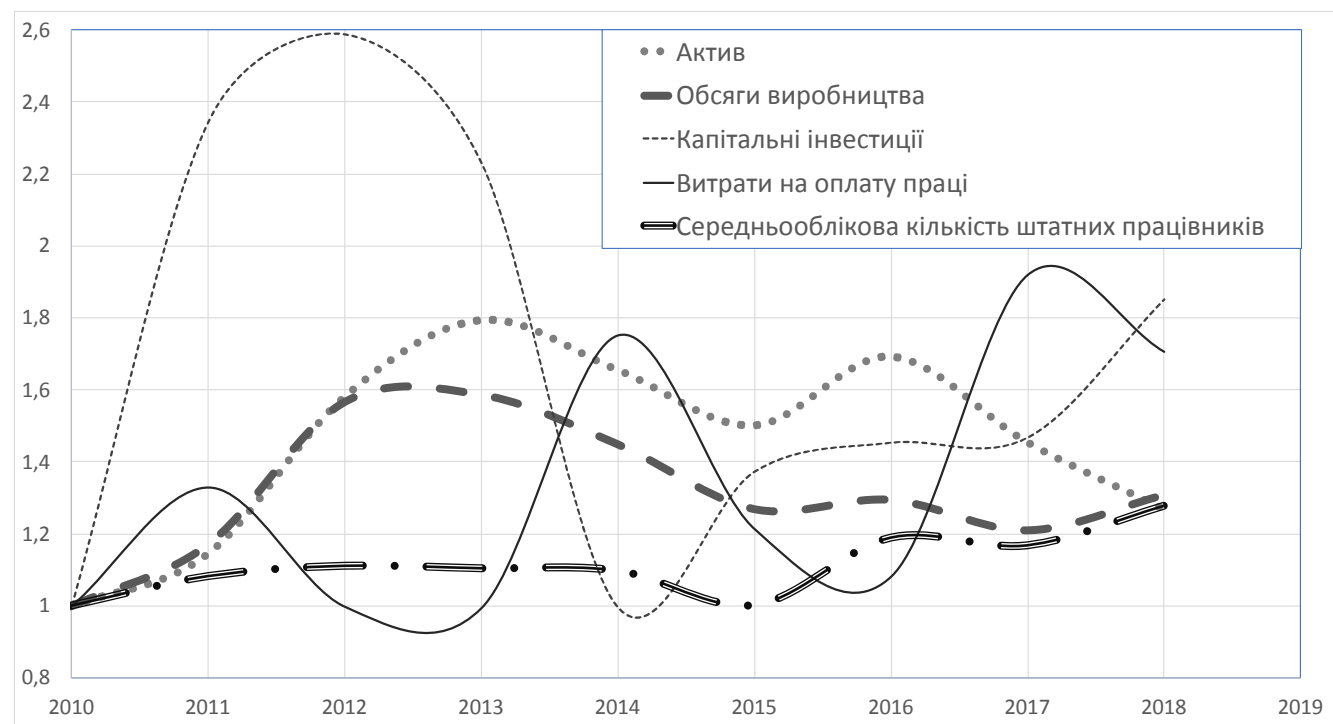

Рисунок 1 - Індекси факторів виробництва та обсягів за період з 2010 по 2018 роки. Базовий 2010 рік

В період з 2010 по 2012 роки спостерігається зріст обсягів виробництва капітальних інвестицій, загального активу галузі та середньооблікової кількості штатних працівників. Винятком у цей період $\epsilon$ показник витрат на оплату праці, який починає спадати після 2011 року. Пояснити це тільки автоматизацією та удосконаленням технологій у галузі не можливо, адже при такій тенденції ми мали б деякий спад у кількості працівників, якого не має в цей період. Більш значущим аргументом буде приховування реальних витрат на оплату праці у галузі по причині сплати податків за працівників. Тому використання цього показника при побудові ВФ, без врахування впливу тіньової економіки не можливо. В період 3 2012 по 2014 спостерігається спад капітальних інвестицій та обсягів виробництва, але темпи спаду капітальних інвестицій набагато швидше за темпи спаду обсягів виробництва, що призводить нас до точки між 2013 та 2014 роками, де капітальні інвестиції вже не можуть виступати фактором капіталу у ВФ по тій причині, що у сукупності індекси капіталу та праці вже не будуть середнім індексом випуску. 3 цих причин використання капітальних інвестицій у побудові ВФ, теж призведе до серйозних відхилень та похибок в остаточній моделі. В період з 2015 по 2018 роки спостерігаються спад та підйом обсягів виробництва. Ця тенденція також відображена у поведінці активів галузі та кількості штатних працівників. Крім періоду з 2017 по 2018 роки, там спад активів характеризується зростом обсягів виробництва та кількості штатних працівників, можна зробити висновок, що активність факторів ВФ співпадає з випуском та 
виконується загальне правило визначення індексу випуску як середнього індексів капіталу та правці.

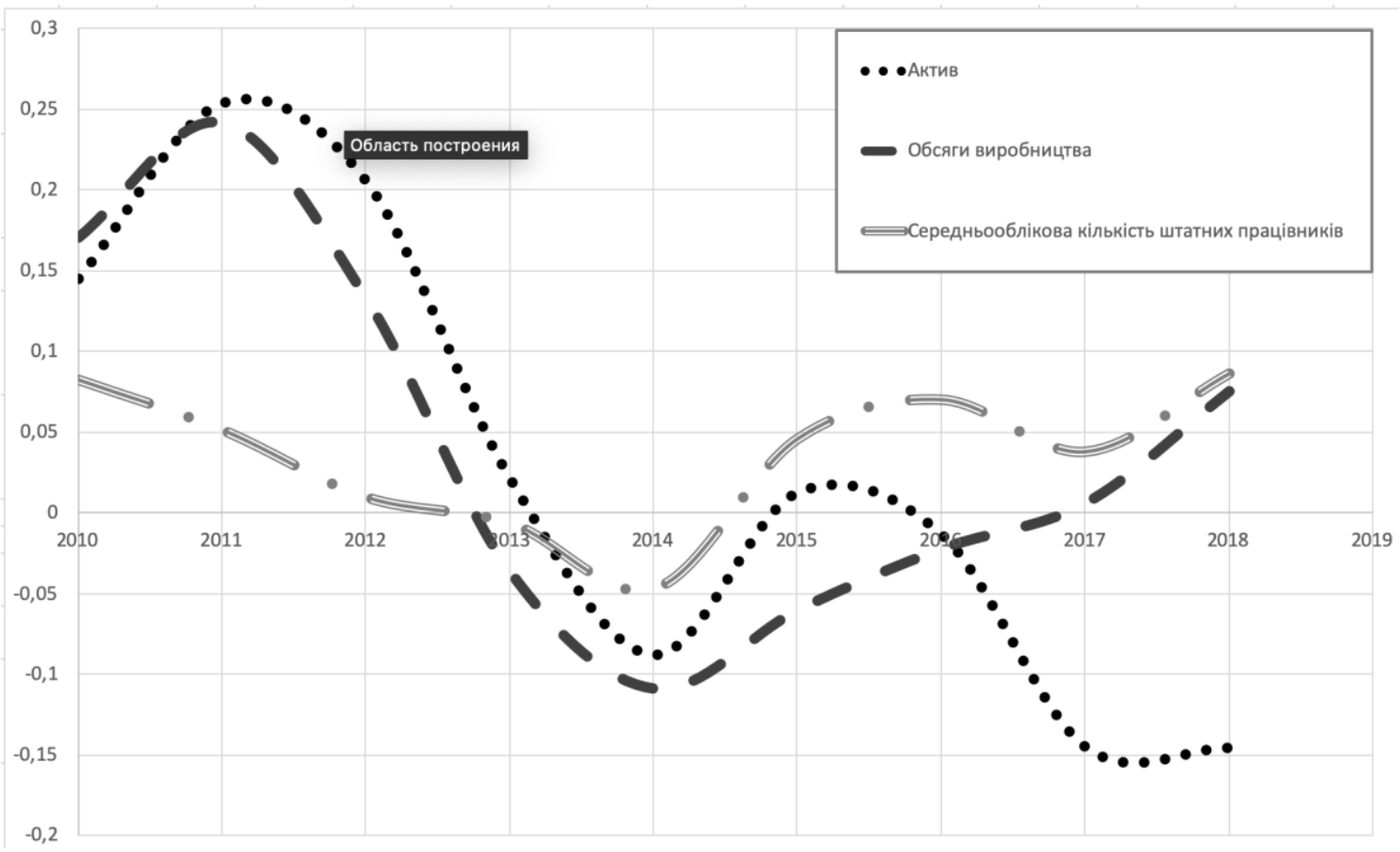

Рисунок 2 - Темпи індексів факторів виробництва та обсягів виробництва за період з 2010 по 2018 роки. Базовий 2010 рік

Далі проілюструємо темпи факторів виробництва в порівнянні 3 темпами обсягів виробництва (див. рис 2). Темпи були розраховані за допомогою методу центральних різниць.

Бачимо що темпи спадання i зростання обсягів виробництва та активів співпадають з 2010 по 2015 роки. 32016 року ці показники мають протилежні напрямки. Тому 3 цього періоду актив як фактор ВФ може призвести до зміщення оцінок параметрів моделі. Складніша ситуація 3 темпами індексу кількості штатних працівників: з 2010 по 2014 він також спадає але набагато повільніше, а з 2014 по 2018 не зважаючи на те, що майже співпадає з зростом обсягів виробництва, все одно темпи обсягу виробництва вже не знаходяться між темпами факторів ВФ. Період 32014 по 2016 можна охарактеризувати як період 3 неефективним використанням факторів ВФ, низькою віддачею від масштабу, або від’ємним показником технічного прогресу.

Спираючись на припущення лінійної однорідності ВФ, можемо проаналізувати залежності $y=f(k)$ та $g=q(l)$ де, $y=Y / L$ - це середня продуктивність праці, $k=K / L$ - це середня фондоозброєність, $g=Y / K$ - 
це середня фондовіддача, а $l=L / K$ - це середня працеозброєнність капіталу.

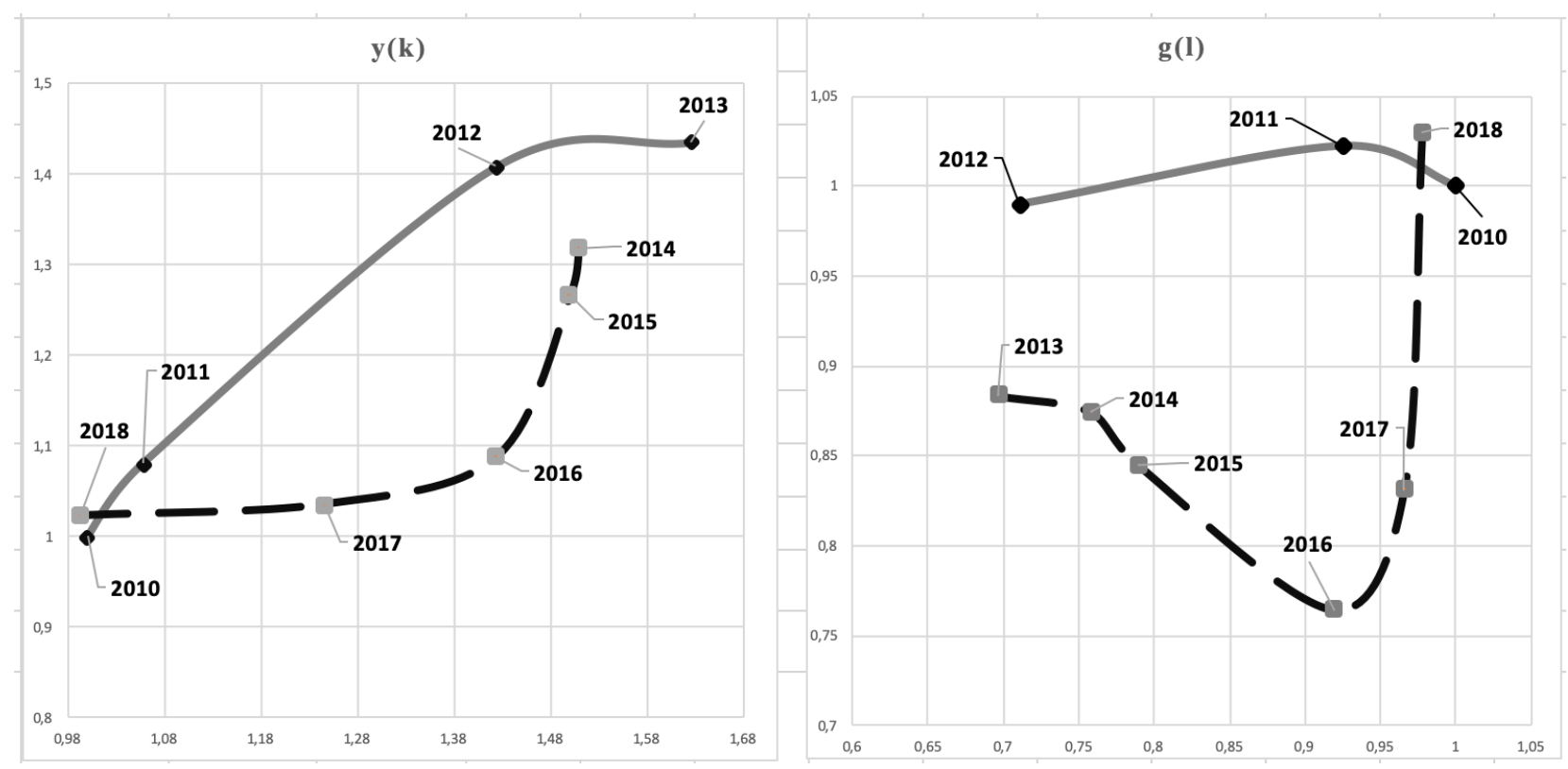

Рисунок 3 - Графіки залежності середньої продуктивності праці у від фондоозброєності k та середньої фондовіддачі g від працеозбороєності капіталу 1 в період з 2010 по 2018 роки

Якщо ВФ задовольняє стандартним припущенням додатних перших похідних та від'ємних других похідних, то це можна буде стверджувати і для функцій $f$ та $q$. Тобто залежності $(y, k)$ та $(g, l)$ мають бути зростаючими та не строго увігнутими [4].

Аналізуючи залежність $(y, k)$ на рис. 3 можемо говорити про зростання $\boldsymbol{y}$ з ростом $\boldsymbol{k}$ в період з 2010 по 2013 роки, а в період з 2013 по 2018 навпаки спадання $\boldsymbol{y}$ зі зменшенням $\boldsymbol{k}$. Залежність $(g, l)$ більш складна, але все ж таки ми можемо виділити період спадання $\boldsymbol{g}$ із зростом $\boldsymbol{l}$ у період з 2013 по 2016 роки та спадання $\boldsymbol{g}$ зі зменшенням $\boldsymbol{l}$ у період з 2011 по 2013 роки.

3 усіх періодів тільки один з 2010 по 2013 роки залежності $(y, k)$ відповідає властивості лінійно однорідної ВФ 3 додатними першими похідним, а всі останні ні. Тобто припущення, що збільшення витрат одного з факторів збільшує випуск не діє на розглянутому інтервалі з 2010 по 2018 роки.

Стосовно властивості других похідних можна говорити про те, що не строга увігнутість спостерігається тільки на інтервалі з 2010 по 2013 роки для першої залежності та на інтервалі за 2011 по 2013 для другої 
залежності. Тобто припущення щодо закону спадної віддачи не діє на інтервалі з 2010 по 2018 роки.

Далі здійсним кореляційно-регресійний аналіз наших даних (див. табл. 2), знайдемо параметри ВФ, та оцінимо тісноту та значущість зв'язку факторів ВФ та випуску.

Таблиця 2 - Індекси факторів ВФ оптової та роздрібної торгівлі за 2010-2018 роки та основні параметри для кореляційного аналізу

\begin{tabular}{|l|c|c|c|c|r|r|r|r|c|}
\hline & $\mathrm{K}$ & $\mathrm{Y}$ & $\mathrm{L}$ & $\widehat{y_{i}}$ & $\left(y_{i}-\hat{y}_{i}\right)^{2}$ & $\left(y_{i}-\bar{y}_{i}\right)^{2}$ & $\ln K$ & $\ln L$ & $\ln Y$ \\
\hline 2010 & 1,000 & 1,000 & 1,000 & 1,036 & 0,001 & 0,100 & 0,000 & 0,000 & 0,000 \\
\hline 2011 & 1,145 & 1,170 & 1,082 & 1,135 & 0,001 & 0,021 & 0,135 & 0,079 & 0,157 \\
\hline 2012 & 1,581 & 1,565 & 1,111 & 1,391 & 0,030 & 0,062 & 0,458 & 0,105 & 0,448 \\
\hline 2013 & 1,795 & 1,585 & 1,104 & 1,505 & 0,006 & 0,072 & 0,585 & 0,099 & 0,461 \\
\hline 2014 & 1,656 & 1,448 & 1,098 & 1,430 & 0,000 & 0,017 & 0,505 & 0,093 & 0,370 \\
\hline 2015 & 1,502 & 1,268 & 1,001 & 1,334 & 0,004 & 0,002 & 0,407 & 0,001 & 0,238 \\
\hline 2016 & 1,693 & 1,294 & 1,190 & 1,461 & 0,028 & 0,000 & 0,527 & 0,174 & 0,258 \\
\hline 2017 & 1,455 & 1,210 & 1,168 & 1,327 & 0,014 & 0,011 & 0,375 & 0,155 & 0,190 \\
\hline 2018 & 1,270 & 1,308 & 1,278 & 1,229 & 0,006 & 0,000 & 0,239 & 0,245 & 0,268 \\
\hline
\end{tabular}

Мультиплікативна модель ВФ має такий вигляд: $Y=A \cdot K^{\alpha} \cdot L^{\beta}$, де:

- Y, K, L - випуск, капітал, трудові ресурси відповідно;

- $\alpha, \beta$ - коефіцієнти еластичності капіталу і трудових ресурсів;

- А - коефіцієнт технічного прогресу.

За методом МНК отримуємо такі основі параметри мультиплікативної моделі ВФ: $A=1.03 ; \alpha=0.61 ; \beta=0.16$.

Не дивлячись на те, що модель $є$ значущою за критерієм Фішера: $F=6.33 ; F_{\text {табл }}=5.14 ; F>F_{\text {табл, }} \quad$ коефіцієнт множинної $R=0.68$ дуже низький.

Отже, можемо зробити висновок, що сукупність факторів виробництва таких як актив та середньооблікова кількість штатних працівників не дуже вдало пояснює обсяги виробництва, що є у галузі торгівлі. 
Спробуємо поширити кількість факторів, сукупність яких може пояснити обсяги виробництва на базі тих показників, облік яких ведеться державною статистикою. Умовно поділимо їх на 3 групи (див. табл. 3). 1 група це фактори, які можна віднести до сукупного капіталу торгівельної галузі. 2 група це фактори, які можна віднести до сукупної праці. 3 група це опосередковані фактори, які частино можна віднести до капіталу в контексті інвестицій у галузь, обсяги виробництва інших галузей та обсяги вантажних перевезень. Мета показників 3 групи компенсувати сукупні недоліки у формуванні реального капіталу галузі, який приймав участь у створенні наявних обсягів виробництва за статистичними даними.

Детальний візуальний аналіз, усіх можливих комбінацій приведених факторів, який ми робили попередньо $є$ дуже громіздким для такої кількості моделей, тому на першому етапі відсіємо ті моделі в яких скоригований коефіцієнт кореляції буде нижчий за 0.75 , не буде виявлено мультиколінеарності, буде низька ймовірність гетероскедастичності та автокореляції залишків моделі (порогові значення для 9 спостережень тесту Дарбіна-Уотсона при $\alpha=0.01$ [0.408;1.389]), відхилення індексу обсягів виробництва та його темпів як середнього індексів капіталу та праці буде менше за 44\% (тобто з 9 років тільки в 4 роках обсяг не буде середнім значенням капіталу та праці).

Як бачимо, найбільш вдало обсяги виробництва пояснює парна регресійна модель 3 такими показниками як: кількість зайнятих працівників суб'єктів господарювання та середньомісячна заробітна плата штатних працівників.

Кількість найманих працівників практично співпадає 3 кількістю найманих працівників тому модель 3 цим показником ідентична першій.

Щодо споживчих сукупних витрат господарств та обсягів виробництва у будівельній галузі, то вони мають досить багато відхилень від обсягів виробництва у торгівлі у темпах (dY deviation) та індексах $(Y$ deviation) див. рис 4. та рис. 5. Тому моделі парних регресій з їх участю будуть менш точно пояснювати обсяги виробництва. 
Таблиця 3 - Статистичні показники, які можуть виступати в якості факторів виробництва торгівельної галузі

\begin{tabular}{|c|c|c|}
\hline Група 1 & Група 2 & Група 3 \\
\hline $\begin{array}{l}\text { необоротні активи } \\
\left(K \_n e o \_a c t\right)\end{array}$ & $\begin{array}{c}\text { витрати на оплату праці тис. } \\
\text { грн (Labor_costs) }\end{array}$ & $\begin{array}{c}\text { споживчі сукупні витрати } \\
\text { домогосподарств } \\
\text { (Consumer_agg) }\end{array}$ \\
\hline $\begin{array}{l}\text { оборотні активи } \\
\left(K \_o b \_a c t\right)\end{array}$ & \multirow{2}{*}{$\begin{array}{c}\text { кількість найманих } \\
\text { працівників у суб’єктів } \\
\text { господарювання } \\
\text { (Hired_count) }\end{array}$} & $\begin{array}{c}\text { неспоживчі сукупні витрати } \\
\text { домогосподарств } \\
\text { (Non_consumer_agg) }\end{array}$ \\
\hline $\begin{array}{c}\text { необоротні активи та } \\
\text { групи вибуття } \\
\left(K \_o u t \_a c t\right)\end{array}$ & & $\begin{array}{c}\text { обсяг перевезених вантажів } \\
\text { поїзда тис.т } \\
\text { (Cargo_vol_train) }\end{array}$ \\
\hline \multirow[t]{2}{*}{$\begin{array}{c}\text { власний капітал } \\
\left(K \_o w n\right)\end{array}$} & \multirow{3}{*}{$\begin{array}{c}\text { кількість зайнятих } \\
\text { працівників у суб’єктів } \\
\text { господарювання } \\
\text { (Working_count) }\end{array}$} & $\begin{array}{c}\text { обсяг перевезених вантажів } \\
\text { авто тис.т } \\
\text { (Cargo_vol_auto) }\end{array}$ \\
\hline & & \\
\hline $\begin{array}{l}\text { довгострокові } \\
\text { зобов’язання } \\
\text { (K_long_loan) }\end{array}$ & & $\begin{array}{c}\text { обсяг перевезених вантажів } \\
\text { авіа тис.т } \\
\text { (Cargo_vol_avia) }\end{array}$ \\
\hline $\begin{array}{c}\text { поточні зобов'язання } \\
\text { (K_short_loan) }\end{array}$ & \multirow{2}{*}{$\begin{array}{c}\text { середньомісячна заробітна } \\
\text { плата штатних працівників } \\
\text { (Avg_salary) }\end{array}$} & $\begin{array}{c}\text { обсяг перевезених вантажів } \\
\text { загальний тис.т } \\
\text { (Cargo_vol_all) }\end{array}$ \\
\hline $\begin{array}{c}\text { капітальні інвестиції } \\
\text { (K_invest) }\end{array}$ & & $\begin{array}{c}\text { обсяги виробництва } \\
\text { сільського господарства } \\
\text { (Y_agriculture })\end{array}$ \\
\hline $\begin{array}{c}\text { результат від } \\
\text { операційної } \\
\text { діяльності } \\
\text { (Op_res) }\end{array}$ & \multirow{2}{*}{$\begin{array}{l}\text { Кількість суб’єктів } \\
\text { господарювання } \\
\text { (Subject_count) }\end{array}$} & $\begin{array}{c}\text { обсяги виробництва } \\
\text { промисловості } \\
\text { (Y_industry) }\end{array}$ \\
\hline $\begin{array}{c}\text { витрати операційної } \\
\text { діяльності } \\
\text { (Op_expenses) }\end{array}$ & & $\begin{array}{c}\text { обсяги виробництва } \\
\text { будівництва } \\
\text { (Y_construction })\end{array}$ \\
\hline
\end{tabular}


Таблиця 4 - Результати кореляційно-регресійного аналізу 4 моделей 3 найбільшим коефіцієнтом $\mathrm{R}$, побудованих на основі статистичних показників

\begin{tabular}{|l|c|c|c|c|}
\hline Model & Working_count & Hired_count & K_ob_act & Working_count \\
Avg_salary & Avg_salary & Consumer_agg & Y_construction \\
\hline R_adj & 0.85 & 0.84 & 0.78 & 0.78 \\
\hline Durbin-Watson & 1.3 & 1.3 & 1.5 & 1.2 \\
\hline p-value & 0.028 & 0.024 & 0.027 & 0.047 \\
\hline Breusch-Pagan & 2.6 & 2.7 & 2.4 & 2.1 \\
\hline p-value & 0.28 & 0.26 & 0.30 & 0.34 \\
\hline VIF_1 & 1.2 & 1.2 & 1.4 & 1.2 \\
\hline VIF_2 & 1.2 & 1.2 & 1.4 & 1.2 \\
\hline Chi-Square & 1.07 & 0.96 & 2.22 & 1.23 \\
\hline Y deviation & 0.00 & 0.00 & 0.00 & 0.44 \\
\hline dY deviation & 0.33 & 0.33 & 0.56 & 0.22 \\
\hline
\end{tabular}

* первинні статистичні данні сформовані на основі джерела [7]

Отже за статистичними даними та кореляційно-регресійним аналізом фактори виробництва у рамках моделі виступають заробітна плата та кількість працівників. Оборотний капітал може виступати як фактор виробничої функції тільки частково, з 2016 року (див. рис 5) він вже може призвести до значних похибок у моделі. Така ж тенденція спостерігалася для кількості працівників у період з 2013 по 2015 роки. Цікавим є те, що незважаючи на кризовий 2014 рік темпи виробництва, оборотних активів та заробітної плати є дуже схожими.

Відкритим залишається питання чи можна віднести заробітну плату працівників як фактор капіталу у структурі виробничої функції. Відповідь 
буде позитивною, але у розрізі такого ключового поняття як - людський капітал.

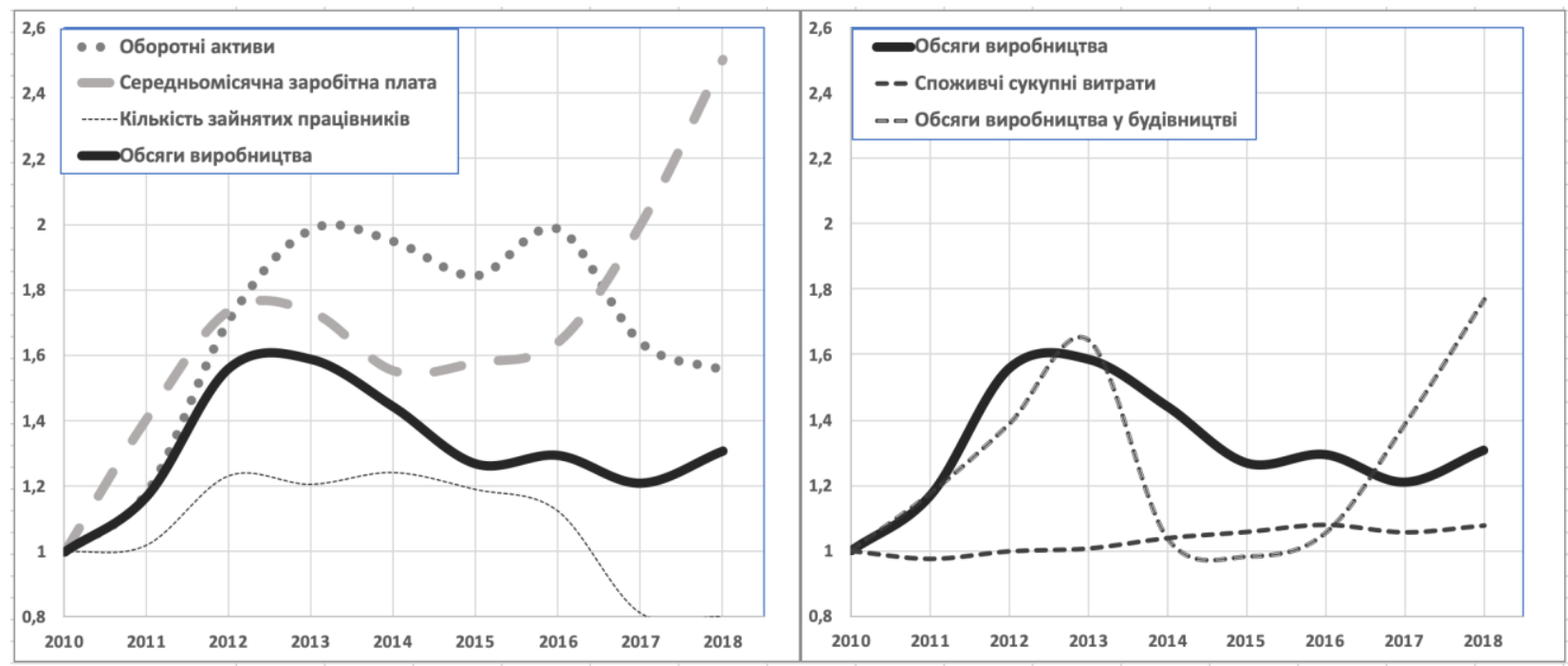

Рисунок 4 - Індекси факторів виробництва та обсягів виробництва за період з 2010 по 2018 роки. Базовий 2010 рік
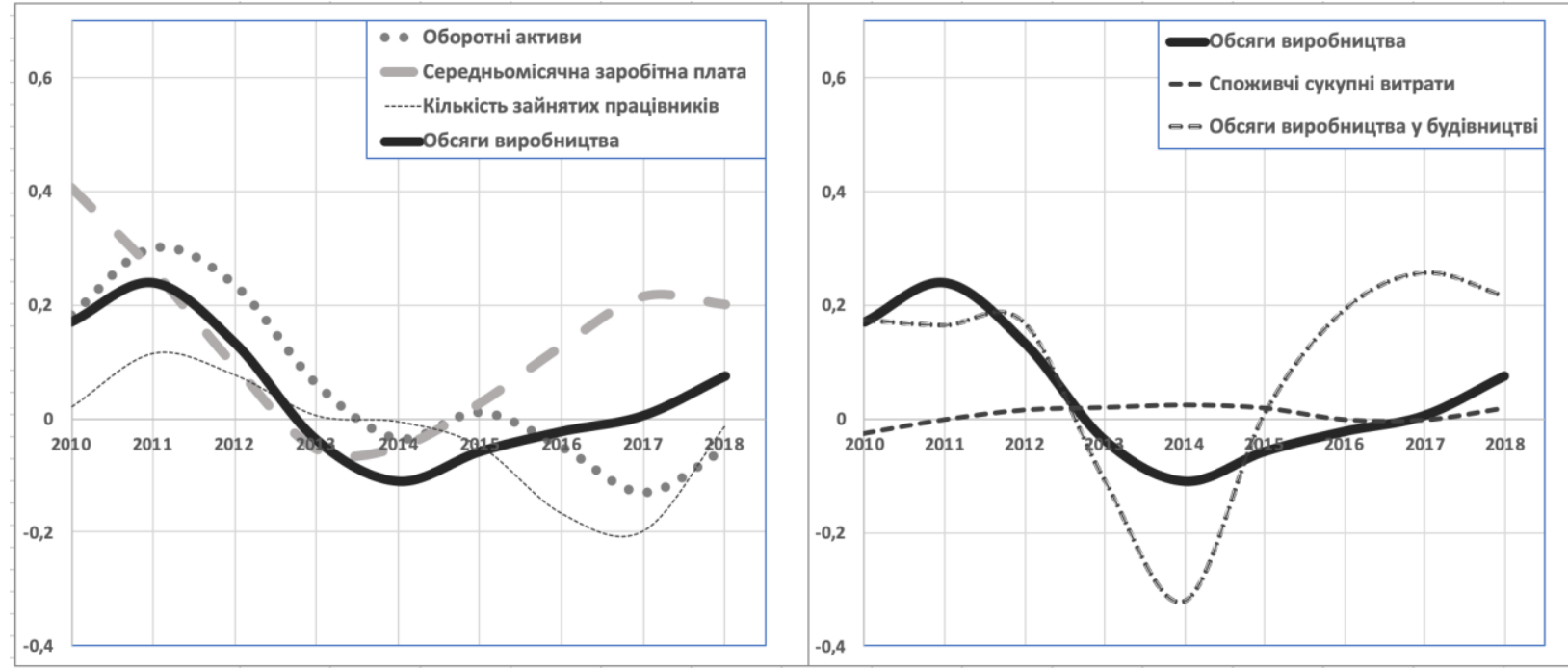

Рисунок 5 - Темпи індексів факторів виробництва та обсягів виробництва за період з 2010 по 2018 роки. Базовий 2010 рік

Саме людський капітал стає ключовим у постіндустріальному суспільстві, а конкретно в наших реаліях та на основі статистичного аналізу - у торгівельній галузі Київської області. Більш детально про людський капітал та обгрунтування того, чи потрібно включати затратні частини виробництва пов'язані з ним до активу підприємства можна дізнатися зі статі [8]. 
Підсумовуючи можемо сказати, що складовими виробничої функції для галузі торгівлі у київській області $є$ заробітна плата (яка є лише частиною більш ширшого фактору, а саме людського капіталу) та кількість зайнятих працівників. За параметрами виробничої функції маємо такі значення $A=0.98 ; \alpha=0.72 ; \beta=0.5$. Коефіцієнт технічного прогресу дорівнює майже одиниці, що говорить нам про неістотний вплив цього фактору у галузі. Сума еластичності за капіталом та працею $\alpha+\beta>1$ говорить нам про позитивний ефект розширення масштабів виробництва, та про те, що функція не є лінійно-однорідною.

Висновки. У ході аналізу галузевої структури Київської області було 3'ясовано, що майже половина всього обсягу виробництва припадають на галузь оптової та роздрібної торгівлі. При пошуку суттєвих факторів виробництва було з'ясовано, що такі фактори як капітальні інвестиції та витрати на оплату праці не можуть пояснити динаміку обсягів виробництва на усьому часовому інтервалі. При більш ширшому аналізі статистичних показників виявилось, що найбільш вдало у рамках мультиплікативної ВФ обсяги виробництва можуть пояснити середньомісячна заробітна плата штатних працівників та кількість зайнятих працівників суб'єктів господарювання. При умові застосування такої конфігурації факторів для моделі ВФ можна надати такі рекомендації щодо напрямку розвитку галузі та регіону в цілому:

1. Зміна акценту інвестицій зі звичайного капіталу на людський капітал. Статистичний аналіз показав дуже опосередкований зв'язок капітальних інвестицій на об’єм випуску. Це не означає відмову від нагромадження та удосконалення існуючого капіталу, а лише звертає увагу на людський фактор, який на даному часовому проміжку $є$ найбільш впливовим.

2. На даний час складові людського капіталу включені до витратної частини фінансового обліку підприємств, але 3 вище зазначених результатів аналізу, є підстави віднести деякі витратні статі трудових ресурсів до активу підприємства, а саме: навчання персоналу, підвищення кваліфікації та заробітну плату [8]. Останній показник можна вводити не повністю, а встановивши деякий поріг кваліфікованості, після якого вже очевидно, що такий працівник його знання та ідеї - не витратна частина, а актив підприємства. 


\section{Література:}

1. Сурай А. С. Інституціональний підхід до розуміння формування та функціонування ділового середовища регіону //Науковий вісник Міжнародного гуманітарного університету. Серія: Економіка і менеджмент. - 2017. - №. 26 (2). C. 32-35.

2. Омельянчик Д.А. Агентно-орієнтоване моделювання економіки: особливості, види, проблеми // Теорія оптимальних рішень. Москва: МГУ, 2013. 49 с.

3. Замрій А. М. Моделювання процесу технологічного переозброєння Київського регіону / А. М. Замрій, В. О. Капустян // Економічний вісник Національного технічного університету України "Київський політехнічний інститут". - 2019. - № 16. - С. 431-442.

4. Шумська С. С. Інструмент виробничої функції в дослідженні української економіки //Економіка та прогнозування. - 2007. - №. 4. - С. 104-123.

5. Бессонов В. А., Цухло С. В. Проблемы построения производственных функций в российской переходной экономике //Бессонов ВА, Цухло СВ. - 2002. - С. 5-89.

6. Державна служба статистики України. [Електронний ресурс]. - Режим доступу до ресурсу: http://www.ukrstat.gov.ua/

7. Головне управління статистики у Київській області [Електронний ресурс]. Режим доступу до ресурсу: http://kyivobl.ukrstat.gov.ua/

8. Головай Н.М. Вкладення в людський капітал і заробітна плата: обліковий аспект / Н.М. Головай //Формування ринкової економіки: зб. наук. праць. Спец. вип. «Управління людськими ресурсами: проблеми теорії та практики». - К.: КНЕУ, 2007. - T. 1. - Ч. 1. - 520 c. 